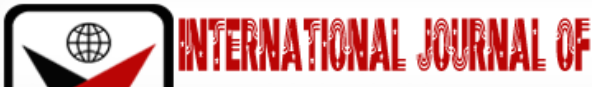

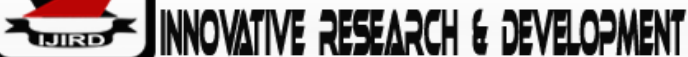

ISSN 2278-0211 (Online)

\section{Challenges of E-Governance in Public Service Delivery in Ghana}

\author{
Dennis Botwe Kyei \\ Student, School of Public Services and Governance, \\ Ghana Institute of Management and Public Administration (GIMPA), Ghana
}

\begin{abstract}
:
The Government of Ghana has taken steps and initiatives to provide speedy and quality services to Ghanaians through e-governance, but the success of e-governance depends on the availability of legal frameworks and policies backed by proactive measures. The purpose of the study is to review and understand the e-governance strategies applied in Ghana's public service delivery and the challenges associated with the implementation of these e-governance initiatives. Dwelling on secondary data, the study's findings indicates that several polices and frameworks support egovernance initiatives in Ghana, but their implementations are burdened with social, cultural, political, and legal constraints.
\end{abstract}

Keywords: E-governance, policies, legal frameworks, ICT, public service, implementation

\section{Background}

The need for equity in the distribution of the national cake and enhancing public good requires effective and efficient public service delivery, thus the need to incorporate technology and technical know-how. A review of the challenges associated with public service delivery as well as the status of their quality dimensions will aid in mapping out strategies to ensure the achievement of the objectives of e-governance. Electronic governance (e-governance) is the use of efficient Information and Communication Technologies (ICTs), mainly the Web-based Internet applications for improved governance and service delivery through open communication, participation, transparency and public dialogue in formulating national regulations (Reddick, Chatfield \&0jo, 2017). The Government of Ghana (GOG) has reiterated its unflinching commitment to leverage on technology and digitization to strengthen and improve the delivery of service within the country's public sector which comprises of institutions and establishments charged with the responsibility of providing services for the public (AsamoahOsei-Kojo\& Yeboah-Asiamah,2013). This is evidenced in the passage of the Electronic Transaction Act, 2008 Act 772 was passed to facilitate electronic transactions online between government, businesses, and the general public (Mathapoly-Codjoe, 2015). Officially on $6^{\text {th }}$ April 2010, E-governance started off as eGhana project in Ghana (Otabil \& Agbenorto, 2010) with its component III having some public agencies captured as a pilot measure which yielded a lot of success. This was done by adopting different ICTs and other e-governance solutions in ensuring better efficiency, transparency, and accountability. In 2012, the project started with agencies like Ghana Immigration Service, The Ghana Revenue Authority (GRA), Registrar General's Department, Accra Metropolitan Assembly (AMA), Birth and Death Registry, Driver and Vehicle Licensing Authority (DVLA), Ghana Police Service, Ghana Tourism Authority, Minerals Commissions, Ministry of Foreign Affairs, Parliament, and the Judicial Service of Ghana (NITA, n.d).This paper examines the concern and risk perceptions of e-governance, identifies the e-governance strategies (policies and frameworks) used Ghana's public service delivery, the challenges associated with its implementation

\section{Concern and Risk Perceptions of E-Governance}

Concerns have however been raised about the extent to which e-governance systems have borne the anticipated results (Abdelkader, 2015) given the fact that some technological hitches like the lack of shared benchmarks and compatible arrangement among departments and agencies affects their service delivery. Trust related issues such as the protect information from alteration, unapproved access, information use and disclosure, interference, inspection, scrutiny, destruction or recording (Enocson, 2018) and also website tracking, information sharing, and the disclosure or mishandling of private information have become of a universal concern (Online Trust Alliance, 2018) have also emerged. E-governance has not been spared with organizational hazards as its implementation principles and functions demand new set of rules, policies, laws and governmental changes that cover electronic activities like electronic archiving, electronic signatures, transmission of information, data protection, computer crime, and intellectual property rights, copyright. The lack of ICT skills especially in developing countries like Ghana with a number of drawbacks such as the lack of qualified staff, inadequate training and low levels of literacy in ICT by citizens (Teshome, Tolossa, Mandefro\&Alamirew, 
2013). This situation makes citizens often rely on intermediaries who Fredriksson (2014) contends aid individuals and firms with the bureaucratic processes of governance but are often tagged with labels of corruption and welfare losses in most developing countries as is the case in Ghana's public sector where the presence of these 'gorro boys' seem not to extinguish. This stifles the objective of bringing governance to the doorstep of the citizenry through e-governance.

\section{Methodology}

The exploratory design was adopted for this study being a two-phased approach with qualitative data explaining or building upon initial results. This study also employed a literature review methodology which is a way of collecting and synthesizing previous research. More specifically, the semi-systematic review approach served as a good strategy for the study of the challenges of e-governance in public service delivery in Ghana. It mapped theoretical methods or themes while detecting knowledge gaps within the literature which this study subscribed to. Guided by the relativist philosophical stance that states that the nature of reality is socially constructed from multiple sources and that the knowledge generated from this study is relative to Ghana's public sector, a qualitative approach was used (Chaowdhury, 2015). Data sources were secondary in nature, thus from journals, publications, reports, brochures, policy, and institutional documents, online and offline. Data analysis was done by identifying, analyzing, and reporting patterns for thematic analysis and consulted documents for textual analysis. Inclusion and Exclusion Criteria was used to ensure that only relevant studies were included in this systematic literature review. Research articles collected for this study span from 2015 to 2018 in digital databases which related to the progression of e-governance from manual to digital implementation in Ghana.

\begin{tabular}{|c|c|c|}
\hline No: & Title of Study \& Author(s) & Study Focus \\
\hline 1 & $\begin{array}{l}\text { Techno Legal Support for E-Governance and } \\
\text { Implementation Challenges in Ghana } \\
\text { Authors: Asare-Nuamah, P. \&Agyepong, D.E. (2016). }\end{array}$ & $\begin{array}{l}\text { To review and understand the various legal } \\
\text { policies and framework. }\end{array}$ \\
\hline \multirow[t]{3}{*}{2.} & $\begin{array}{c}\text { An Assessment of Ghana's Global E-Government UN } \\
\text { Ranking } \\
\text { Author: Agboh, D. (2017) }\end{array}$ & $\begin{array}{c}\text { To assess Ghana's global e-government ranking, } \\
\text { review the objectives and procedures, review } \\
\text { some causes of the low e-service delivery ranking, } \\
\text { and recommend solutions to improving future } \\
\text { rankings. }\end{array}$ \\
\hline & Ghana e-Government Interoperability Framework & \\
\hline & $\begin{array}{c}\text { Assessing the Implementation Of E-Government in } \\
\text { Ghana's Public Sector } \\
\text { Author: Mathapoly-Codjoe, E. (2015) }\end{array}$ & $\begin{array}{l}\text { Assessing the Implementation of E-Government in } \\
\text { Ghana's Public Sector }\end{array}$ \\
\hline
\end{tabular}

Table 1: Data Sources

Source: Author's Construct (2020)

\section{Findings}

\subsection{E-Governance Strategies Used in Ghana's Public Service Delivery}

The Ghana e-Government Interoperability Framework (e-GIF) of Ghana which describes the policies necessary to ensure successful implementation of the e-GIF by instituting an agreed approach to interoperability (the ability of disparate IT products and services to exchange and use data and information). This ensures the synergetic functioning of governmental products and services in a networked environment and thus lead to improvement in government services with internal efficiencies and the provision of better online access. A set of policies institutes the technical standards and guidelines covering ways to achieve interoperability of public-sector data and information resources for information and communications technology (ICT), electronic business processes, e-GIF integrates Ministries, Departments, or Agency (MDA) through a scheduled framework based on international standards.

The scope of the e-GIF implementation is grounded on the different types of interactions like those between government and individuals on issues of tax collection, health care, lands registry, business, and industry (planning regulations, import and export). Using the Internet and World Wide Web specifications for all government systems, the Government of Ghana's (GoG) data interchange strategy is to espouse XML and XSL as the primary benchmarks for data integration and administration. This includes the definition of the GoG XML schemas and metadata model, which have been created by GGEA Data Architecture Reference Model. The scope of the e-GIF also includes the detailed technical standards and policies for interoperability.

While Information Technology (IT) has provided great strides for greater efficiencies in state government, IT has been an impediment for the most part in providing greater flexibility and creativity in crossing other MDA application boundaries for common services and service reuse, which is the next step of automation delivery. To this end, the Service Oriented Architecture (SOA), an interoperability concept has been advanced to support the implementation of Web services, applications which are constructed as sets of re-useable, co-operating services with each being responsible for one or more clearly identified and bounded user tasks, business processes or information services.

Among the notable policies and laws regulating e-governance activities in Ghana are:

- $\quad$ National Telecommunication Policy (2005)

- $\quad$ National Information Technology Agency Act (2008), Act 771

- $\quad$ National Communication Authority Act (2008), Act 769

- $\quad$ Electronic Transaction Act (2008), Act 772 
- $\quad$ Electronic Communication Act (2008), Act 775

- Ghana Information and Communication Technology for Accelerated Development (ICT4AD) Policy (2003).

There are some challenges of E-governance related to IT infrastructure, Managerial issues, Digital Culture, Laws and budgeting. (Asare-Nuamah and Agyepong, D.E. (2016); Amegavi, Bawole and Buabeng ,2018).

\section{Discussions of Finding}

The main objective of e-governance is to allow the public sector to provide citizens with information based on their need, hence increasing their effectiveness, efficiency, and quality of service (UN 2016).Individual behavior such as utilization of new innovation is driven by behavioral intentions, where behavioral intentions is a function of an individual's attitude toward the behavior, the subjective norms surrounding the performance of the behavior, and the individual's perceptions of the ease with which the behavior can be performed. The direct determinants of people's behavioral intentions are their attitudes towards performing the behavior, awareness of innovation, social pressure (networks and interactions), and the subjective norms associated with the behavior. Services offered through e-governance portal are key motivating factors stakeholders to accept and successively use the portal. Adoption of a portal by citizen or customers is directly related to theservices' availability and accessibility. Customer orientation is a key imperative for attracting more citizens/customers to an e-government portal and improving service quality. The instrumental aspect of e-governance initiatives is the evaluation of the real benefit of the technological systems. This involves consideration of which stakeholder interests should be evaluated.

\section{Suggestions}

The study can be appliedbygoverning and implementation agencies in the provision of material resources, financial and personnel resources.The implications of this study for further research can focus on mass awareness through the promotion and marketing of e- governance initiatives and policies, citizens education and participation in the formulation of e-governance policies and initiative as well as the extension of information and communication technology infrastructure to the rural poor.

\section{Conclusion}

This study helps to identify the strategies used as well as the e-governance implementation challenges in Ghana's public sector. The speedy and high-quality services help to fulfill the needs of citizens. It causes a dynamic shift in governance, particularly in the democratic settings. E-governance mainly causes enhancement of the objectives of egovernance, legal policies and framework are essential for e- governance initiatives. This study also highlights several policies and frameworks that pertain to e-governance exist in Ghana along with constraints which need to be addressed to enjoy the full benefits of e-governance.

\section{Conflicts of Interest}

The authors declare no conflicts of interest regarding the publication of this paper.

\section{References}

i. Abdelkader, A. (2015). A manifest of barriers to successful e-government: Cases from the Egyptian programme. International Journal of Business and Social Sciences, 6(1).

ii. Agboh, D. (2017). An assessment of Ghana's global e-government UN ranking. Available athttp://www.aabri.com/AC2017Manuscripts/AC17046.pdf.

iii. Amegavi, G.B., Bawole, J.N., \&Buabeng, T. (2018). The dynamics of e-government enactment in developing country public sector organization evidence from Ghana. International Journal of Electronic Governance, 10(1): 74-92.

iv. Asamoah, K., Osei-Kojo, A., \&Yeboah-Assiamah, E. (2013). Enhancing public sector productivity in Ghana: A qualitative study. Journal of Public Administration and Governance, 3(3).

v. Asare-Nuamah, P. \&Agyapong, D.E. (2016). Techno Legal Support for E-Governance and Implementation Challenges in Ghana. Future of E-government: learning from the Past'. Socrates Indexed Scholarly Journal,Vol. 4 No. 3 (2016) Issue- September. ISSN $2347 \quad 6869 \quad$ (E) \& ISSN 2347-2146 (P).

vi. Chowdhury, I. A. (2015). Issue of quality in qualitative research: an overview. Innovative Issues andApproaches in Social Sciences. 8. 142-162. 10. 12959/issn. 1855-0541. IIASS2015 n01-art09.

vii. Enocson, J, (2018). Prevention of Cyber Security Incidents within the Public Sectora qualitative case study of two public organizations and their way towards a sustainable cyber climate.Department of Management and Engineering, Linkoping University, Sweden. ISRN: LIUIEI-FIL-A-18/02935-SE

viii. Mathapoly-Codjoe, E. (2015). Assessing the Implementation of E-Government in Ghana's Public Sector. (MPhil Thesis University of Ghana).

ix. National Information Technology Agency, Ghana. (2014). Ghana e-government interoperability framework. Retrieved from Government \%20Interoperability\%20Framework.pdf.

x. National Information Technology Agency, Ghana. (2015). E-Government network infrastructure.Retrieved from http://www.nita.gov.gh/eGovernment-Network-Infrastructure.

xi. Online Trust Alliance (2018). Cyber Incident and Breach Trends Report. Available at www.internetsociety.org 
xii. Otabil, A. \&Agbenorto, M. (2010). E-Government network project commenced. Information Service Agency, Accra.

xiii. Reddick, C., Chatfield, A. T., \&Ojo, A. (2016). A social media text analytics framework for double-loop learning for citizen-centric public services: A case study of a local government Facebook use. Government Information Quarterly.34.10.1016/j.giq.2016.11.001.

xiv. Teshome, W., Tolossa, D., Mandefro, F., \&Alamirew, B. (2013). Governance and Public Service Delivery: The Case of Water supply and Roads Services Delivery in Addis Ababa and Hawassa Cities, Ethiopia. Institute of Regional and Local Development Studies, Addis Ababa University.

xv. UN E-Government Survey (2016). Available:www.publicadministration.un.org 